\title{
DISTRIBUTION OF THE GENUS CEDRELA IN ECUADOR
}

\author{
Silvia Alejandra Llerena ${ }^{1}$, Natalia Salinas ${ }^{2}$, Luiz Orlando de Oliveira ${ }^{3}$, \\ Mónica Jadán-Guerrero ${ }^{4}$, Claudia Segovia-Salcedo ${ }^{4}$ \\ ${ }^{1}$ Department of Ecology. Peoples Friendship University of Russia \\ 8/5, Podol'skoe shosse, Moscow, 115093, Russian Federation \\ ${ }^{2}$ Department of Horticultural Sciences University of Florida \\ Florida, 32611, United States \\ ${ }^{3}$ Department of Biochemistry and Molecular Biology. Federal University of Viçosa \\ Av. Peter Henry Rolfs, s/n - University Campus, Viçosa-MG, 36570-900, Brazil \\ ${ }^{4}$ Departamento de Ciencias de la Vida y Agricultura. Universidad de las Fuerzas Armadas ESPE \\ Av. General Rumiñahui S/N, Sangolquí, 171103, Ecuador
}

\begin{abstract}
The genus Cedrela in Ecuador has four species: C. odorata, C. montana, C. fissilis and C. nebulosa. Cedrela was one of the economically most important timber in the past, due to its wood properties. The genus has a long history of overharvesting and selective logging; as a consequence a substantial genetic degradation have occurred in Ecuador. Currently, three species of Cedrela are included in the IUCN Red List. C. odorata and C. nebulosa are listed as vulnerable species and C. fissilis as endangered species. In spite of their conservation status and priority, few studies related to geographical distribution have been done. Then, the geographic distribution at local level had been carried out to provide a valuable tool to the conservation and management of these species. Field sampling and herbarium compilation showed C. montana is restricted to the Ecuadorian highlands in the western and eastern Andean montane region between 805 to 3200 masl (meters above sea level). Cedrela nebulosa is located in Andean region about 1400 to 2300 masl. C. odorata is the most widely distributed, occupying areas in the Amazon (200-1300 masl), Pacific (330-825 masl) and insular regions (350 masl). While, Cedrela fissilis is only found in the Amazon Region about 200 to 510 masl. This basic information about current distribution and abundance of cedar species is primordial to generate sufficient tools to formulate the strategies of management and conservation of these species in the country. The widespread distribution of $C$. odorata have been found in the Amazonian and Pacific regions, indicating that it is adapted to tropical rainforest and tropical monsoon climates. To prove if there are adaptations to both habitats morphological, ecological and phylogenetic studies must be carried out.
\end{abstract}

Key words: Cedrela, endangered species, ecoregion, altitude

\section{INTRODUCTION}

Each year between 2010 and 2015, worldwide 7,6 million hectares (ha) of forest were lost due to the deforestation. South America is not an exception, is one of the continents with the highest rate of deforestation (2 million ha/year) [6]. Same as Ecuador with one of the highest rates of the Continent according to the Food and Agriculture Organization of the United Nations (annual rate of $1.8 \%$ for the 2001-2010 period) and the main causes are related to urban sprawl, expansion of agricultural and pasturelands, lack of 
adequate government policies, high demand for timber products, logging and forest fires $[15 ; 16 ; 26]$.

Although, the annual rate of deforestation in Ecuador has been reduced in recent years, it continues affecting a large range of species, such as Cedrela. Cedar is demanded by the timber and construction industries due to the high quality of its wood in terms of color, fragrance, strength and durability $[3 ; 8 ; 17)$.

In Ecuador, the genus Cedrela P. Browne (Meliaceae) includes 4 species: Cedrela odorata, $C$. fissilis, $C$ montana and $C$. nebulosa [21]. These species have shown a huge decrease in their population size and distribution due to their high quality timber. According to CITES data between 2002 to 2009, Ecuador exported $342 \mathrm{~m}^{3}$ of cedar wood, however in the international market, this wood replaced collapsed sales of other species such as mahogany, this lasted a couple of years before collapsing the exports. Furthermore, the selective logging of big and better formed trees is a common practice in Ecuador, which erodes the genetic quality of the remain populations [21;25]. Other threats to the future survival of this genus are the expansion of human settlements, conversion of land for agricultural and livestock use, the construction of highways and the extraction of oil and minerals [26]. All of these threats trigger the genetic diversity diminish and generate problems in the conservation and management policies of these plants. As a consequence of the selective logging of cedar, C. fissilis is an endangered species and Cedrela odorata is considered as a vulnerable species [10].

Despite the economic and ecological relevance of the genus Cedrela, studies on the current status and the distribution of its species in Ecuador are scarce $[11 ; 21 ; 22]$. This study provides information about the distribution of Cedrela genus in Ecuador, which can be a valuable contribution to the management of these species.

\section{METHODS}

Georeference data was obtained of herbarium specimen.s from the National Herbarium of Ecuador (QCNE), Herbarium of the Pontificia Universidad Católica del Ecuador (QCA), Ministry of the Environment (MAE) and Walter Palacios, the expert in Meliaceae. In addition, data was included from field collections of the Phylogeography of Cedrela [14]. Two hundred forty seven specimens (247) were collected and georeferenced (Garmin Etrex Summit and Magellan Meridian Platinum GPS).

The map of geographical distribution of the genus Cedrela in Ecuador was generated using data collected and vegetable formations division of the continental Ecuador [2; 12; $20 ; 23]$. ArcGIS 10.3 Software was used in this study.

\section{RESULTS AND DISCUSION}

On large scale, there was a clear division in the geographical distribution of Cedar species in Ecuador: Cedrela montana is distributed in the Andean Region between 805 and 3200 meters above sea level; C. nebulosa in the Andean Region in heights between 1420 to 2300 masl; Cedrela odorata was the most widespread species located in three regions: Pacific (330-825 masl), Amazonian (200-1300 mas) and Insular region at 350 m. Cedrela fissilis was found only in the Amazon Region at elevations between 200 and 510 masl (Fig. 1 and 2). 


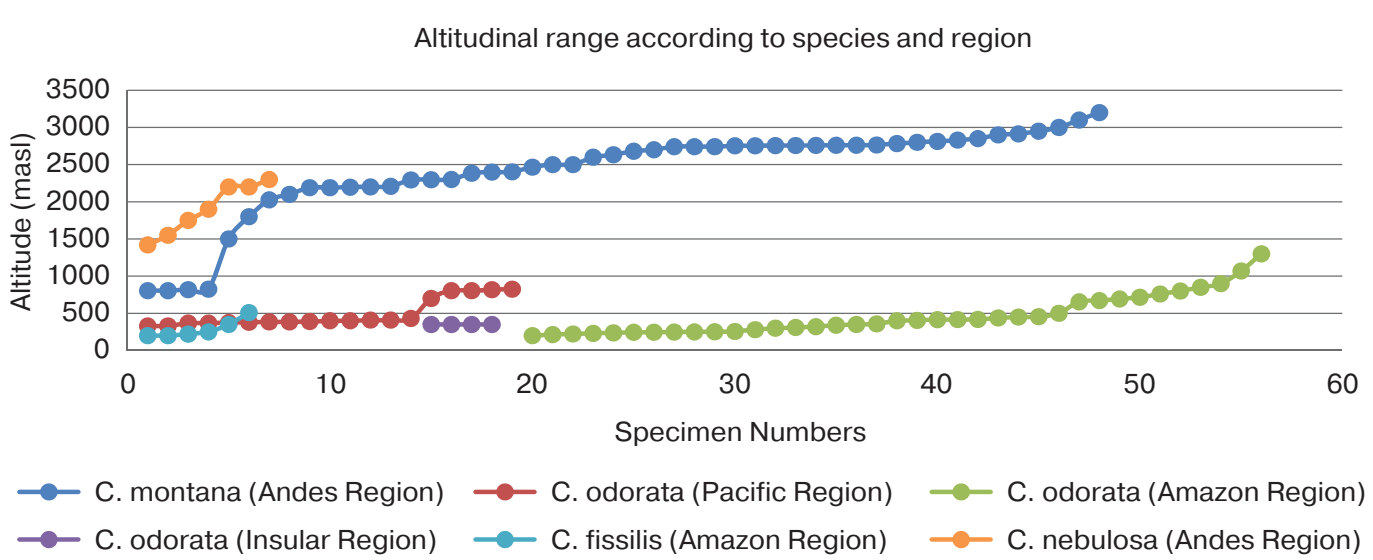

Fig. 1. Scatter plot of Cedar species distribution by altitudinal range and region

The Cedar distribution in the Ecoregions of Ecuador classified by [23; 20] showed a notorious preference of each species to different formations. As shown in Figure 2, the most widely distributed species was Cedrela odorata, found in the following Ecoregions: Lowland Evergreen Forest of the Amazon, and Flooded Lowland Forest of the Amazon at heights from 200 to 1300 masl. In the Pacific Region it was presented in Lowland Evergreen Forest, Piedmont Evergreen Forest of the Coast Mountains and Deciduous Forest of Lowlands, at heights from 330 to 825 masl. In Galápagos Islands C. odorata was found in the Xeric Scrub Ecoregion at 350 masl.

Cedrela montana was restricted to the Andean Region in the following Ecoregions: Lower Montane Evergreen Forest and Montane Mist Forest of the Western Andes, Lower Montane Evergreen Forest of the North and Central Andes, and High Montane Evergreen Forest of the Eastern Andes in heights between 805 and 3200 masl. In the previous Ecoregion and in the Montane Mist Forest of the Eastern Andes, the species C. nebulosa was also located in heights between 1420 to 2300 masl. Cedrela fissilis appeared only in the Amazon Region in the Lowland Evergreen Forest and Flooded Forest of the Amazon at heights between 200 to 510 masl (Fig. 2).

The regions where Cedrela species were located are enclosed in three different biodiversity hotspots. C. odorata in the Coast Region (Mache Chindul Ecological Reserve and Maglares Churute Nature Reserve) is located in Chocó-Darién-Western Ecuador Hotspot [4]. Both, Cedrela odorata and C. fissilis in the Amazon and Cedrela montana is in the Hotspot of the Tropical Andes (Table 1).

The $C$. odorata distribution determine that is adapted to two habitat types: tropical rainforest and tropical monsoon where the climate is warm dry and warm humid in the regions of the Central and Insular Coast and in the North Coast and Amazon Regions, respectively. Adaptations due to growth in different regions have been recorded in previous studies [18; 19], where it was established that $C$. odorata populations of Xeric (high solar radiation and low humidity) and Mesics environments (higher humidity and lower radiation) of Costa Rica differ in morphological and adaptive characteristics such as seed weight, seedling size, root neck diameter (RND) of the seedling, leaf size, weight of the sheet. In Xeric environment $C$. odorata populations showed higher values in the morphological characteristics than $C$. odorata of Mesics habitat as an adaptation to survive in drought. 


\title{
CEDAR SPECIES
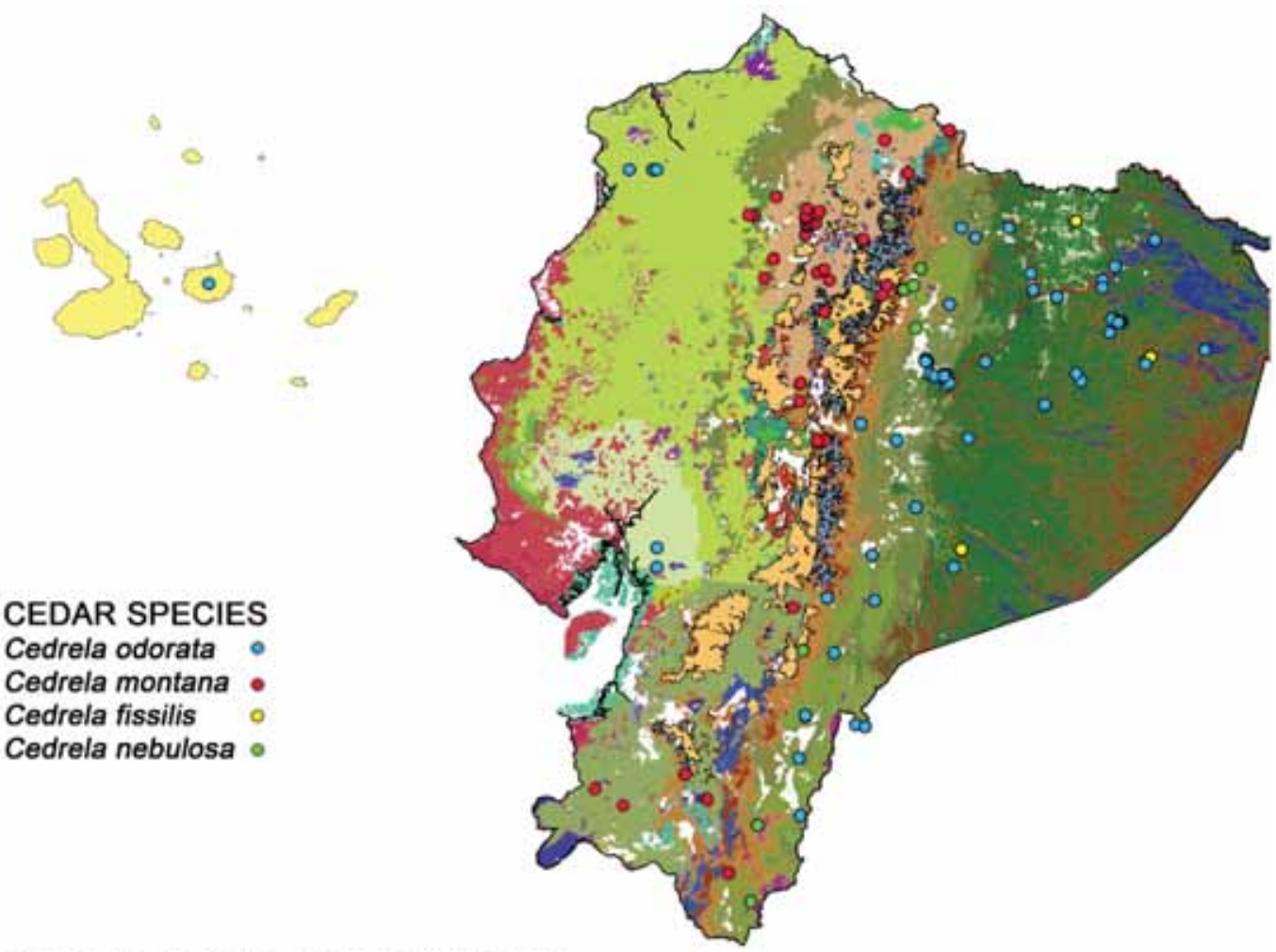

\section{ECOREGIONS OF ECUADOR}

\author{
PACIFIC REGION \\ Lowland Evergreen Forest \\ Deciduous Lowlands Forest \\ ANDEAN REGION \\ Lower Montane Evergreen Forest of the Western Andes \\ Montane Mist Forest of the Western Andes \\ Lower Montane Evergreen Forest of the North and Central Andes \\ Montane Mist Forest of the Eastern Andes \\ $\square$ High Montane Evergreen Forest of the Eastern Andes \\ AMAZON REGION \\ Lowland Evergreen Forest of the Amazon \\ Piedmont Evergreen Forest \\ Flooded Lowland Forest of the Amazon \\ INSULAR REGION \\ Xeric Scrub
}

Fig. 2. Map of Cedrela Distribution in Ecuador based in the plant formations classification of Sierra et al (1999) and Olson (2002). Symbology: C. odorata, blue circle; C. montana, red circle;

C. fissilis, yellow circle and C. nebulosa, green circle (ArcGis 10.3)

The leaves of $C$. odorata sampled in dry and humid environments showed differences in size. In addition, in the research developed by [14] about molecular phylogenetics of Cedar in Ecuador using chloroplasidic genes cpDNA and transcripted internal spacers (ITS) was suggested a possible incipient speciation and/or a subspecies status over $C$. odorata populations. The two lineages found for this species were correlated with the region of distribution, one from the Central Coast Region and Insular Region (dry climate) and the other from the North Coast and Amazon Region (humid climate). However, to 
corroborate this hypothesis it is suggested to perform morphological and ecological studies to determine the parameters on which the dry and humid environments caused a selective pressure and therefore its adaptation.

Table 1

Summary of cedrela species location according to hotspot and plant formations

\begin{tabular}{|c|c|c|}
\hline Species & $\begin{array}{l}\text { Hotspot }(\mathrm{h}) \\
\text { or Region }(\mathrm{r})\end{array}$ & $\begin{array}{c}\text { Plant formation } \\
\text { (Sierra et al., 1999; Olson, 2002) }\end{array}$ \\
\hline \multirow[t]{6}{*}{ Cedrela odorata } & \multirow[t]{3}{*}{ Amazonía (r) } & Lowland Evergreen Forest of the Amazon \\
\hline & & Piedmont Evergreen Forest \\
\hline & & Flooded Lowland Forest of the Amazon \\
\hline & \multirow[t]{2}{*}{ Choco-Darien (h) } & Lowland Evergreen Forest \\
\hline & & Deciduous Lowlands Forest \\
\hline & Island $(r)$ & Xeric Scrub \\
\hline \multirow[t]{4}{*}{ Cedrela montana } & \multirow[t]{4}{*}{ Tropical Andes (h) } & Lower Montane Evergreen Forest of the Western Andes \\
\hline & & Montane Mist Forest of the Western Andes \\
\hline & & Lower Montane Evergreen Forest of the North and Central Andes \\
\hline & & High Montane Evergreen Forest of the Eastern Andes \\
\hline \multirow[t]{2}{*}{ Cedrela nebulosa } & \multirow[t]{2}{*}{ Andes (h) } & High Montane Evergreen Forest of the Eastern Andes \\
\hline & & Montane Mist Forest of the Western Andes \\
\hline \multirow[t]{2}{*}{ Cedrela fissilis } & \multirow[t]{2}{*}{ Amazon $(r)$} & Lowland Evergreen Forest of the Amazon \\
\hline & & Flooded Lowland Forest of the Amazon \\
\hline
\end{tabular}

Cedrela montana and C. nebulosa share the same Andean region, however the first one is more widely distributed. This ecoregions are characterized by the frequent presence of moving fog. The climate is pluvial humid to hyperhumid and the soil is well moist and drained. The altitudinal range between both species also varies slightly, being that C. montana can reach a higher altitude of up to 3200 masl. Finally, C. fissilis was the least dispersed and in a lower altitudinal range, it was located only in the Amazon region.

\section{CONCLUSION}

With the exception of the studies of [21], there is only scarce information on current distribution of cedar in Ecuador; with this study is cleared the distribution of cedar taking to consider the altitude and the ecoregions where each species develops. Also we found that $C$. odorata of tropical rainforest and tropical monsoon climates shows morphological differences like the size leaf. To prove if there are adaptations to both habitats morphological, ecological and phylogenetic studies must be carried out.

The distribution of cedar has been observed to be restricted to tree main regions depending of each species. All of these regions coincide with highly deforested areas, hence, Cedrela genus must be consider a priority conservation group due to their vulnerability to extinction as a result of anthropogenic activities that destroy or modify the environment; In general, deforestation in Ecuador has shown a high rate and is one of the main cause to the climate change with important implications for ecosystem functioning and biodiversity conservation [24]. The deforestation plays an important role in increasing global warming because has enhanced emission of greenhouse gases such as carbon dioxide, methane, and nitrous oxide, especially it has contributed $6-17 \%$ of global anthropogenic $\mathrm{CO}_{2}$ emissions to the atmosphere [1; 5; 9]. Therefore, deforestation 
avoidance is helpful for supporting reduced greenhouses gases and also provides other benefits such as conservation of ecosystem biological diversity, prevention of forest fragmentation, protection of watersheds, improvement of local livelihoods, and provision of additional income for developing countries [13;16].

The threat of species is the direct consequence of Cedrela logging, in particular C. fissilis which is as a rare species (restricted distribution and sparse populations) and in danger of extinction. Therefore, the cedar reforestation can improve the current state of Cedrela in Ecuador; in order to have a good reforestation management, the actual distribution and the habitat preferences of each species must be considered. In addition, because cedar distribution concurs with biological 'hotspot', it has a high conservation value [24] owing hotspots have been considered such prior areas to research about of the origin of the biologic diversity [7].

\section{Acknowledgments:}

The research was generously supported by University of Armed Forces-ESPE (Ecuador). We gratefully acknowledge the collaboration of the Plant biotechnology Laboratory especially to Dr. Karina Proaño. We express thanks to Cedral Ecolodge, National Herbarium of Ecuador (QCNE), Herbarium of the Pontifical Catholic University of Ecuador (QCA), Ministry of the Environment (MAE) and Walter Palacios for permitting to collect data for it study with permission number FLORA No. 0015 MAE-DPO-PNY.

\section{REFERENCES}

[1] Baccini, A., Goetz, S.J., Walker, W.S., Laporte, N.T., Sun, M., Sulla-Menashe, D., Hackler, J., Beck, P.S.A., Dubayah, R., Friedl, M.A., Samanta, S. and Houghton, R.A. 2012. Estimated carbon dioxide emissions from tropical deforestation improved by carbon-density maps. Nature Climate Change 2, 182-185.

[2] Báez, S., Salgado, S., Santiana, J., Cuesta, F., Peralvo, M., Galeas, R., Josse, C., Aguirre, Z., Navarro, G., Ferreira, W., Cornejo, X., Mogollón, H., Ulloa, C., León-Yánez, S., Ståhl, B \& Toasa, G. 2010. Propuesta Metodológica para la Representación Cartográfica de los Ecosistemas del Ecuador Continental. Ministerio de Ambiente del Ecuador (MAE) \& Consorcio para el Desarrollo Sustentable de la Ecoregión Andina (CODESAN). Quito-Ecuador. (pp. 28-36; 95-178).

[3] Cavers, S., Navarro, C., \& Lowe, A. 2003. Chloroplast adn phylogeography reveals colonisation history of a Neotropical tree, Cedrela odorata L., in Mesoamerica. Molecular Ecology 12, 14511460.

[4] Critical Ecosystem Partnership FUND (CEPF). 2005. Chocó-Manabí Conservation Corridor. Colombia and Ecuador. Available at: http://www.cepf.net/Documents/final. chocodarienwesternecuador.chocomanabi.briefingbook.pdf (date of access: 10/11/16).

[5] Fearnside, P. and Laurance, W. 2004. Tropical deforestation and greenhouse-gas emissions. Ecological Applications, 14(4).

[6] Food and Agriculture Organization of the United Nations Rome, 2016 Global Forest Resources Assessment 2015. Available at: http://www.fao.org/3/a-i4793e.pdf (date of access: 15/12/16).

[7] Garcia, M., Santos, R., Carniello, M., Veldman, J., Bandini, A., \& Oliveira, L. 2011. Molecular evidence of cryptic speciation, historical range expansion, and recent intraspecific hybridization in the Neotropical seasonal forest tree Cedrela fissilis (Meliaceae). Molecular Phylogenetics and Evolution 61, 639-649.

[8] Hernández, G., Buonamici, A., Walker, K., Vendramin, G., Navarro, C., \& Cavers, S. 2007. Isolation and characterization of microsatellite markers for Cedrela odorata L. (Meliaceae), a high value neotropical tree. Conservation Genetics 9, 457-459. 
[9] Herzog, S., Martinez, R., Jørgensen, P., \& Tiessen, H. 2011. Climate Change and Biodiversity in the Tropical Andes. MacArthur Foundation, Inter American Institute for Global Change Research (IAI) \& Scientific Committee on Problems of the Environment (SCOPE).

[10] IUCN. (2016). IUCN Red List of Threatened Species. Version 2016-2. <www.iucnredlist.org>. Downloaded on 17 November 2016.

[11] IUFRO, International Union of Forest Research Organizations in Brisbane, Australia. (2008). "Sustainable management of highvalue timber species of the Meliaceae: a global perspective": Introduction. Forest Ecology and Management 255, 265-268.

[12] Josse, C., Navarro, G., Comer, P., Evans, R., Faber-Langendoen, D., Fellows, M., Kittel, G., Menard, S., Pyne, M., Reid, M., Schulz, K., Snow, K., \& Teague, J. 2003. Ecological Systems of Latin America and the Caribbean: A Working Classification of Terrestrial Systems. NatureServe: Arlington, Virginia. USA.

[13] Lawrence, D. 2014. Effects of Tropical Deforestation on Climate and Agriculture

[14] Llerena, S., Jadán, M. \& Proaño, K. 2012. Filogeografía molecular de las especies Cedrela odorata, Cedrela fissilis y Cedrela montana (meliaceae) del ecuador mediante el uso de genes cloroplastídicos cpADN y espaciadores internos transcritos (ITS). Tesis de pregrado. Laboratorio de Biotecnología Vegetal. Escuela Politécnica del Ejército.

[15] Ministery of enviornment (MAE). 2012 / Línea Base de Deforestación del Ecuador Continental, Quito-Ecuador. http://sociobosque.ambiente.gob.ec/files/Folleto\%20mapa-parte1.pdf

[16] Moutinho, P. and Schwartzman, S. 2005. Tropical Deforestation and Climate Change. Amazon Institute for Environmental Research

[17] Muellner, A., Pennington, T., Koecke, A., \& Renner, S. 2010. Biogeography of Cedrela (Meliaceae, Sapindales) in Central and South America. American Journal of Botany 97, 511-518.

[18] Navarro, C., \& Vázquez, W. 1987. Genetic variability in seeds and seedlings of Cedrela odorata. Paper presentado en el Congreso Forestal Nacional de Costa Rica, San Jose, Costa Rica. Centro Agronómico Tropical de Investigación y Enseñanza (CATIE).

[19] Navarro, C., Ward, S., \& Hernandez, M. 2002. The tree Cedrela odorata (Meliaceae): a morphologically subdivided species in Costa Rica. Revista Biologia Tropical 50, 21-29.

[20] Olson, D.M. and E. Dinerstein. 2002. The Global 200: Priority ecoregions for global conservation. (PDF file) Annals of the Missouri Botanical Garden 89: 125-126. The Nature Conservancy, USDA Forest Service and U.S. Geological Survey, based on Bailey, Robert G. 1995. Description of the ecoregions of the United States (2nd ed.). Misc. Pub. No. 1391, Map scale 1:7,500,000. USDA Forest Service. 108pp. The Nature Conservancy (2003), based on Wiken, E.B. (compiler). 1986. Terrestrial ecozones of Canada. Ecological Land Classification Series No. 19. Environment Canada, Hull, Que. 26 pp. + map.

[21] Palacios, W. 2011. "Situación de Swietenia macrophylla King y Cedrela odorata L. en el Ecuador" (inédito). Quito: TRAFFIC-UICN.

[22] Rull, V. 2007. On the origin of present Neotropical biodiversity: a preliminary meta-analysis about speciation timing using molecular phylogenies. Orsis 22, 105-119.

[23] Sierra, R., Cerón, C., Palacios, W., \& Valencia, R. 1999. Mapa de vegetación del Ecuador Continental. Escala 1:1000.000. Proyecto INEFAN/GEF-BIRF, Widlife Conservation Society y EcoCiencia. Quito, Ecuador.

[24] Tapia-Armijos, M.F., Homeier, J., Espinosa, C.I., Leuschner, C., De La Cruz, M. 2015. Deforestation and Forest Fragmentation in South Ecuador since the 1970s - Losing a Hotspot of Biodiversity. PLoS ONE. 10(9).

[25] Varela, F. 1997. Genetic Resources of Swietenia and Cedrela in the Neotropics: Proposals for Coordinated Action. Forest Resources Division. Forestry Department Food and Agriculture Organization of the United Nations. FAO, Roma. Italia. Proyecto FAO/GCP/RLA/128/NET.

[26] Zúñiga, S. (1999). Memoria del Taller sobre el programa de Evaluación de los Recursos Forestales en once países Forestales. Situación actual de la forestación y reforestación en el Ecuador. INEFAN. Ecuador. Organización de las Naciones Unidas para la Agricultura y la Alimentación (FAO). Agencia Sueca para el Desarrollo Internacional (SIDA). Centro Agronómico Tropical de Investigación y Enseñanza (CATIE). Available at: http://www.fao.org/docrep/007/ad102s/ AD102S00.htm\#TopOfPage (date of access: 20/01/17). 


\title{
Article history:
}

Received: 25.02 .2017

Revised: 01.03.2018

\section{For citation:}

Silvia Alejandra Llerena, Natalia Salinas, Luiz Orlando de Oliveira, Mónica Jadán-Guerrero, Claudia Segovia-Salcedo. (2018) Distribution of the genus CEDRELA in Ecuador. RUDN Journal of Ecology and Life Safety, 26 (1), 125-133. DOI 10.22363/2313-2310-2018-26-1-125-133

\section{Bio Note:}

Silvia Alejandra Llerena - Master in Ecology and Nature Management, Department of Ecology. Peoples Friendship University of Russia. E-mail: alellerenag@gmail.com

Natalia Salinas - PhD (c), Department of Horticultural Sciences. University of Florida. United States

Luiz Orlando de Oliveira - PhD genetics and plant breeding, Department of Biochemistry and Molecular Biology. Federal University of Viçosa. Brazil-MG.

Mónica Jadán-Guerrero - PhD (c), Departamento de Ciencias de la Vida y Agricultura. Universidad de las Fuerzas Armadas ESPE. Av. General Rumiñahui S/N. Sangolquí. Ecuador.

Claudia Segovia-Salcedo - PhD in Molecular Systematics, Departamento de Ciencias de la Vida y Agricultura. Universidad de las Fuerzas Armadas ESPE. Av. General Rumiñahui S/N. Sangolquí. Ecuador.

\section{РАСПРОСТРАНЕНИЕ РОДА ЦЕДРЕЛА В ЭКВАДОРЕ}

\author{
Сильвия Алехандра Йерена ${ }^{1}$, Наталья Салинас ${ }^{2}$, Луиз Орландо де Оливеира ${ }^{3}$, \\ Моника Хадан Герреро ${ }^{4}$, Клаудия Сеговиа Салцедо ${ }^{4}$ \\ ${ }^{1}$ Кафедра экологии. Российский университет дружбы народов \\ Российская Федерация, 115093, Москва, Подольское шоссе, 8/5 \\ ${ }^{2}$ Кафедра садоводства. Университет Флориды \\ США, 32611, Флорида \\ ${ }^{3}$ Кафедра химии и молекулярной биологии. Федеральный университет Викоза \\ Бразилия, 36570-900, Викоса, ул. Питер Генри Рольфс \\ ${ }^{4}$ Кафедра естественных наук и сельского хозяйства. \\ Университет вооруженных сил - ESPE \\ Эквадор, 171103, Санголки, просп. Главн. Руминьяви
}

\section{История статьи:}

Дата поступления в редакцию: 25.02.2017

Дата принятия к печати: 01.03.2018

\section{Для цитирования:}

Йерена С.А., Салинас Н., де Оливеира Л.О., Герреро М.Х., Салцедо К.С. Распространение рода Цедрела в Эквадоре // Вестник Российского университета дружбы народов. Серия: Экология и безопасность жизнедеятельности. 2018. Т. 26. № 1. С. 125-133. DOI 10.22363/23132310-2018-26-1-125-133 


\section{Сведения об авторах:}

Йерена Сильвия Алехандра - магистр экологии и природопользования кафедры экологии Российского университета дружбы народов. Москва-Россия E-mail: alellerenag@gmail. com

Салинас Наталья - кандидат технических наук кафедры садоводства Университета Флориды. США

де Оливеира Луиз Орландо - кандидат наук (генетика и селекция растений) кафедры биохимии и молекулярной биологии Федерального университета Викоза. Бразилия.

Герреро Моника Хадан - кандидат наук $\mathrm{PhD}$ (c) кафедры естественных наук и сельского хозяйства Университета вооруженных сил - ESPE. Санголки, Эквадор.

Салцедо Клаудия Сеговиа - кандидат наук PhD в области молекулярной систематики кафедры естественных наук и сельского хозяйства Университета вооруженных сил - ESPE. Санголки, Эквадор. 